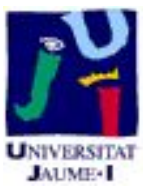

Título artículo / Títol article: Politics in Spain: A Case of Monitory Democracy

Feenstra, Ramón A. ; Keane, John

Revista:

VOLUNTAS: International Journal of Voluntary and Nonprofit Organizations October 2014, Volume 25, Issue 5

Versión / Versió:

Preprint de l'autor

Cita bibliográfica / Cita

FEENSTRA, Ramón A.; KEANE, John. Politics in bibliogràfica (ISO 690): Spain: A case of monitory democracy. VOLUNTAS: International Journal of Voluntary and Nonprofit Organizations, 2014, 25.5: 1262-1280.

url Repositori UJI: http://hdl.handle.net/10234/125344 


\section{Politics in Spain: A Case of Monitory Democracy}

Feenstra, Ramón A. ; Keane, John

\section{Introduction}

The current period is one of economic and political complexity and disruption in Spain (Charnock et al. 2011). The severe economic crisis, cuts and corruption are now daily items on the political agenda and have had a significant effect on the way citizens view the core representative institutions (Castells 2012; FnfEurope 2013). Since 2009, surveys from the CIS, Centro de Investigaciones Sociológicas (Sociological Research Centre), have noted a steady discrediting of the political class. During this period, the quality of political leadership and political parties has become the third greatest concern amongst citizens and, since July 2013, the constant proliferation of scandals has placed corruption as the public's second concern. Political disaffection is directed primarily at the two major political parties (PP and PSOE) which dominate Spanish politics. The CIS survey for October 2013 reported voting intentions for the PP at 34\%, and $26.8 \%$ for the PSOE, a total of $60.8 \%$ of all votes, down significantly from previous decades. These polls mirror changes in support for the two dominant Spanish parties: in the March 2008 general elections $83.81 \%$ of all votes went to the PSOE and the PP (43.87\% and 39.94\% respectively). This discrediting of the party duopoly benefits some minority parties like IU and UP\&D, but disaffection is mainly manifested in a trend towards abstention ahead of the next elections ${ }^{1}$.

Public disaffection with the structures of representation has been fuelled by growing political protests since May 2011, principally through the citizen movement known as the 15M (Castells 2012; Della Porta 2013; Postill 2013; Author 1 2012a, pp. 138-143; Castañeda 2012, pp. 131-133; Hughes 2011, pp. 410-411; Anduiza et al. 2013). This movement first burst onto the Spanish political scene through demonstrations and city square occupations (Bennett \& Segerberg 2012, pp. 741-743; Andronikidou and

\footnotetext{
${ }^{1}$ http://datos.cis.es/pdf/Es3001mar_A.pdfhtml (Accessed 2 December 2013).
} 
Kovras 2012: 708; Postill 2013, Taibo 2012). It later matured into other forms of political expression: blocking evictions for mortgage foreclosures, the formation of new 'anti-party' political parties, citizen-based legislative initiatives, and so on (Tormey 2014). From the beginning, the $15 \mathrm{M}$ has pursued a number of key objectives, including 1) altering the Spanish media and political agenda; 2) multiplying points of view that circulate in the public sphere, 3) promoting transparency; and finally 4) denouncing those responsible for the economic and political crisis (Author $12012 \mathrm{~b}$ ). These goals are shared with other active civil society groups, all of which have championed a series of initiatives designed to scrutinise the centres of political and economic power.

This article will examine these initiatives from the perspective of monitory democracy (Author 2 2009, pp. 686-713; 2013; Author 1 2012a, pp. 75-90). Our claim is that monitory democracy is a rich new analytical concept for understanding some basic features of the complex political dynamics in contemporary Spain. In pursuit of this aim, the opening section of the article outlines some vital features of the theory of monitory democracy.

\section{Monitory democracy}

Our claim is that Spain is a type of monitory democracy, an instance of a new historical form of democracy, a variety of 'post-electoral' politics and government defined since the late 1940s by the rapid growth of many different kinds of extra-parliamentary, power-scrutinising mechanisms (Author 2 2009). Supposing the existence of independent publics, to whom their messages are addressed, monitory bodies take root within the 'domestic' fields of government and civil society (Munck 2009), as well as in 'cross-border' settings once subject to the arbitrary power of empires, states and businesses. In consequence, as is happening in many other democracies, the architecture and dynamics of self-government in Spain is changing. The central grip of elections, political parties and parliaments on citizens' lives is weakening. Democracy is coming to mean much more than free and fair elections, although nothing less. Within and outside states, independent monitors of power are beginning to have major tangible effects on the dynamics and meaning of democracy. By putting politicians, parties and elected governments permanently on their toes, monitory institutions complicate their lives and question their power and authority, often forcing them to chop and change their agendas - sometimes by smothering them in political disgrace. 
When judged by its institutional contours and inner dynamics, the monitory democracy that is emerging in Spain is without doubt the most complex form of democracy known in its history. Monitory democracy is a global trend. Those with a taste for Latin would say that it is the tertium quid, the not fully formed successor of the earlier historical experiments with assembly-based and representative forms of democracy. In the name of 'people', 'the public', 'public accountability', 'the people', 'stakeholders' or 'citizens' - the terms are normally used interchangeably in the age of monitory democracy - power-scrutinising institutions spring up all over the place, both within the fields of government and beyond, often stretching across borders, into wider European and global spaces (Saward 2010; Alves, 2013). Elections, political parties and legislatures neither disappear nor decline in importance; but they most definitely lose their pivotal position in politics. Contrary to the orthodox claims of many political scientists (Przeworski et. al. 1999; Przeworski 2010), democracy is no longer simply a way of handling the power of elected governments by electoral and parliamentary and constitutional means, and no longer a matter confined to territorial states. Gone are the days when democracy could be described (and in the next breath attacked) as "government by the unrestricted will of the majority" (von Hayek 1979, p. 39). Whether in the field of local, national or supranational government, or in the world of business and other non-governmental organisations and networks, some of them stretching down into the roots of everyday life and outwards, people and organisations that exercise power in Spain, as elsewhere, are now routinely subject to public monitoring and public contestation by an assortment of extra-parliamentary bodies.

A different way of putting the same point is to say that what is distinctive about the coming of monitory democracy in Spain is that potentially all fields of social and political life come to be publicly scrutinised, not just by the standard machinery of representative democracy, but by a whole host of non-party, extra-parliamentary and often unelected bodies. In the era of monitory democracy, it is as if the principles of representative democracy - public openness, citizens' equality, selecting representatives - are superimposed on representative democracy itself. This has many practical consequences, but one especially striking effect is to alter the patterns of interaction political geography - of democratic institutions. Democracy comes to be synonymous with a mediated galaxy of monitory mechanisms and processes bound up with struggles to chasten and humble the powerful, wherever they exercise power over others. 
The phenomenon of citizen disaffection towards representative structures, parties, parliaments, and elections is not unrelated to this trend (Crouch 2004; Rosanvallon 2011). Disaffection with these institutions should not be understood as a crisis of politics (Tormey 2006, pp. 2-3; Moffitt \& Tormey 2014, Author 1 2012c, pp. 125-126), but as a forceful element in a broader process of change in which the public monitoring of power appears as an alternative form of political participation (Author 2 2009; Rosanvallon 2008, pp. 22-24). Various counter-powers closely examine the decisions made by representatives (Castells 2009); they blow whistles on the powerful when policies or decisions appear to be defective; monitory bodies also act to resist changes they consider undesirable, or act to set things right, for instance by implementing they changes they publicly recommend.

These monitoring processes cannot be understood without taking into account the vital importance of the new digital communications galaxy that enables the birth and growth of parallel publics (Author 2 2005a; 2013). The new architecture of communicative abundance helps to promote the transparency of power centres: various counter-powers and mechanisms that publicly interrogate power obtain access to instruments that can assess and value the actions of those in power through a variety of of monitoring processes. Digital technologies and the new communications environment enable the emergence of the public monitoring of power as a new political dynamic marked by the participation of many civil society organisations and networks in deciding who wins, and who loses (Author 2 2009; Della Porta 2011; Author 1 2012a, pp. 111-143).

\section{Monitoring processes and mechanisms in contemporary Spain}

The perspective of monitory democracy sketched above inevitably prompts many new questions. To what extent can the growth of monitory democracy be observed in the Spanish context? What are the specific scrutiny mechanisms that have been consolidated and what type of public monitoring of power do they actually promote? The questions are challenging, but it is safe to say that there appears to be a growing abundance of initiatives to monitor centres of power in the Spanish political context. The opacity of many public institutions, along with the search for those responsible for the current economic and political crisis, has led to a strengthening of civil society organisations and networks that specialise in promoting the arts of public scrutiny. In 
recent years, civil society and citizens have put under the microscope issues as diverse as the daily actions of public representatives, political corruption in the management of public budgets, the sluggishness of state monitoring mechanisms like the court of auditors, the malfunctioning of structures like the Spanish Senate, the cozy relations between certain elected representatives and large companies, the mortgage system, the lack of transparency in political party funding, aggressive banking policies, the electoral system, to name but a few. All these issues have surfaced within the public sphere as a result of external public pressure (Author 1 2012b; Micó \& Casero-Ripollés 2013).

The dynamic amalgam or heteropolarity of monitoring processes that has emerged during the current Spanish crisis is not an easy subject to approach from a theoretical position. The public monitoring of power in the Spanish context assumes numerous forms, and the actors driving this scrutinising process are manifold, and disparate. The remainder of this essay seeks to bring greater clarity to the subject, initially by identifying various monitoring methods that civil society has invented, and applied, in recent years. Although we are aware of the limitations of every kind of classification of social and political phenomena - simplifications, overlapping processes and the impossibility of grasping each and every characteristic are chronic features of the human sciences (Weber 1978) - we do attempt to reveal the presence of different public scrutiny mechanisms that have gained strength in the Spanish political system, to the point where they show signs of significantly altering its dynamics.

\section{Scrutiny by traditional and alternative media}

One of the striking dynamics to emerge in recent years in Spain has been the consolidation of certain media -both mainstream and alternative- geared to scrutinising the centres of power. Despite the obvious historical alignment between the media and political parties in the Spanish context, several examples show how investigative journalism and the public scrutiny of power have gained strength. The classic definition of journalism as an agent to examine the performance of the political system and to report on abuses of power ('speaking truth to power') can be seen in various channels of both mainstream and alternative media (Kovach \& Rosenstiel 2007; Lievrouw 2011).

A striking example of scrutiny by the mainstream media, and specifically by the press, is the treatment in the news of what is known as the Bárcenas case, after Luis Bárcenas, who was treasurer of the PP (Popular Party) for 20 years and is currently in 
detention for alleged corruption. The press, particularly two newspapers, El País and El Mundo, have played a central role in exposing this corruption scandal, to the point where they have helped set the political and media agenda.

On January 31, 2013 El País newspaper -ideologically close to the PSOE socialist party- published what have become known as the 'Bárcenas papers'. These documents showed what purported to be a PP slush fund for the years 1990 to 2009. El Mundo, which despite being a regular ideological bedfellow of the ruling party, had already published the most sensitive information of this scandal. On January 182013 (i.e., before the Bárcenas papers appeared in El País) El Mundo revealed information pointing to the possibility that the ruling party had been paying out undeclared cash payments through its then treasurer, Luis Bárcenas. Some months later (on July $7^{\text {th) }}, E l$ Mundo published an interview in which Bárcenas admitted to the veracity of the documents disclosed in El País. Just a few days later, on July 14, the same newspaper published controversial text messages sent between the former treasurer and the President of the government, Mariano Rajoy, after the corruption scandal had broken. The controversial information reported in these two newspapers triggered an avalanche of coverage in all the media and also set the agenda in both the legal and political spheres, forcing President Rajoy to appear before the Spanish parliament on August 1 to account for the information published in El Mundo on July 14. Furthermore, as we explain below, the information published by these newspapers spurred alternative media and various collaborative citizen scrutiny processes to investigate the issue in depth.

It is important to note that although this Bárcenas case is widely considered the paradigm example of journalistic monitoring in recent years in Spain, it is not the only issue on which the press has focussed. The press has also scrutinised scandals or controversies surrounding politicians such as the former justice minister, Mariano Fernández Bermejo (PSOE), and the judiciary. A particularly outstanding case involved the president of the Supreme Court in 2012, Carlos Dívar. Likewise, the regional governments of Andalusia, Madrid, the Valencia Community and the Balearic Islands, large companies like Viajes Marsans and Nueva Rumasa, the trade union UGT in Andalusia and members of the royal family continue to come under public scrutiny, to the point where the proliferation of scandals appears to be endless.

Television channels have also been monitoring the centres of power. The most striking instance is Salvados, a programme that began in 2008 as a comedy show and has since evolved into a form of investigative journalism that examines issues affecting 
the country, while still following the entertainment model. Its audience has grown from 885,000 in 2008 to over 3 million viewers in June 2013. The news reports by the Salvados team have a remarkable impact in the new digital media. Many of their revelations go viral, first on the Internet and later within mainstream media (Author 1 2012b). Two of its programmes had the greatest public impact: the interview conducted by the show's front man, Jordi Évole, with the politician Jaume Matas, charged in several cases of corruption; and Olvidados, a programme that recounted details of the 2006 Valencia metro accident in which 43 people were killed. The interview with Matas was used in a court case as relevant documentation. Similarly, the programme Olvidados, during which a former employee of the regional government security department admitted that the accident investigation commission had been manipulated, led to mass protests demanding the re-opening of the inquiry. The content of this programme was widely discussed throughout all mass media.

Not only have traditional media undertaken journalism based on the public scrutiny of the centres of power. Recent years have witnessed the emergence of alternative media guided by the principle of public monitoring and the demand for transparency and accountability. The economic and political crisis has definitely fuelled an alternative model of journalism that explores to the full the potential of the Internet. Interesting recent initiatives include Periodismo Humano, ElDiario.es, Infolibre, Diagonal and La Marea. Although each of these projects to emerge between 2010 and 2013 has its own specific characteristics, they all share a common goal: their support for independent investigative journalism to report on previously unaccountable political and economic power. Their main purpose is the struggle for transparency and citizens' rights to plural information about the way the centres of power operate (Table 2). Finally, the recent volumes to come out of smaller publishers such as Icaria, El Viejo Topo and Popular are scrutinising the Spanish political and economic system, so satisfying growing public demand for greater public accountability of corporate and governmental organisations. 
Table 1

\begin{tabular}{|c|c|c|}
\hline Media & Goals (taken from the media's own sites) & Year founded and website \\
\hline Diagonal & $\begin{array}{l}\text { We are a critical and independent media. We are } \\
\text { communication activists. We try to avoid being swept } \\
\text { along by the fast pace of being permanently up to } \\
\text { date; we are not interested in throw-away information. } \\
\text { We prefer to stop and analyse what is happening, } \\
\text { interpret it and offer frameworks of meaning that help } \\
\text { us to find the right direction and change the rules of } \\
\text { the game. We do not have most of the solutions, but } \\
\text { we seek out the answers. }\end{array}$ & $\begin{array}{l}\text { 2005. In } 2011 \text { it was remodelled } \\
\text { to enter the digital environment. } \\
\text { http://www.diagonalperiodico.net }\end{array}$ \\
\hline $\begin{array}{l}\text { Periodismo } \\
\text { Humano }\end{array}$ & $\begin{array}{l}\text { We want to bring back the social function of } \\
\text { journalism and the concept of public service for } \\
\text { citizens, not to serve particular economic or political } \\
\text { interests. Information is not simply a tradeable asset } \\
\text { or business, but a public good and a right. }\end{array}$ & $\begin{array}{l}2010 \\
\text { http://periodismohumano.com/ }\end{array}$ \\
\hline ElDiario.es & $\begin{array}{l}\text { Among the basic principles defended by the editorial } \\
\text { line at eldiario.es is public transparency: the public's } \\
\text { right to access the information generated by public } \\
\text { administrations and knowledge of how they spend } \\
\text { taxpayer's money. }\end{array}$ & $\begin{array}{l}2012 \\
\text { http://www.eldiario.es }\end{array}$ \\
\hline La Marea & $\begin{array}{l}\text { For us, journalism means sitting in front of the } \\
\text { computer with no kind of political or corporate } \\
\text { pressure conditioning what we write. It means, for } \\
\text { example, being able to publish the name of a bank } \\
\text { responsible for evictions without worrying that they } \\
\text { will withdraw their adverts. This is the only } \\
\text { journalism we believe in. We are committed to } \\
\text { investigative journalism and analysis. Our aim is to } \\
\text { provide information with no ties to business or } \\
\text { political interests. }\end{array}$ & $\begin{array}{l}2012 \\
\text { http://www.lamarea.com/ }\end{array}$ \\
\hline Infolibre & $\begin{array}{l}\text { InfoLibre is an information and civic project that } \\
\text { emerged at a time when the economic crisis is } \\
\text { threatening both democracy and journalism, which are } \\
\text { increasingly subjected to the interests of economic } \\
\text { and financial power. InfoLibre aspires to offer } \\
\text { professional, independent, free, honest, participative, } \\
\text { committed and quality journalism. }\end{array}$ & $\begin{array}{l}2013 \\
\text { http://www.infolibre.es }\end{array}$ \\
\hline
\end{tabular}

\section{Citizen platforms favouring processes of collaborative monitoring and scrutiny}

Other recent examples of consolidated monitoring in the Spanish context include civil platforms focussing on specific issues, such as the scrutiny of specific fields of powersenate, parliament, elected representatives, banks etc.- and controversial decisions or specific corruption scandals. These are civil initiatives where ordinary citizens become specialists in tracking the actions of politicians, in extracting information, in drawing up reports, sharing information or in transcribing information in open formats. Some initiatives are ongoing and remarkably stable. Adopta un senador (Adopt a Senator), Qué hacen los diputados (What do Members of Parliament do?), Civio.org, Sueldos Públicos (Public Salaries) or Cuentas Claras (Clear Accounts) are examples. Other 
examples involve processes of collaborative monitoring, in which various groups work together on an ad hoc basis to scrutinise a specific problem.

Citizens' monitoring platforms have appeared since 2011, when in September of that year the Adopta un senador project was launched; it was inspired by an initiative by The Daily Telegraph in 2009 to publish the expenses statements of members of the House of Commons. Adopta un senador pursued the same aim by offering Internet users the chance to transcribe, in open format, information about the assets of elected representatives of both houses of parliament. This information, first published in PDF format, was transcribed by members of the public in an open Google Docs spreadsheet. In this way, the information could be compared and itemised according to a politician's political party. Each politician's assets were traced; and the accuracy of the information could be cross-checked by citizens themselves.

The year 2011 also saw the creation of Qué hacen los diputados. It was inspired by models such as opencongress.com and openpolis.it (Tascón \& Quintana 2012, p. 49). Its aim is comprehensively to track and disseminate information regarding the parliamentary activity of elected representatives. This platform defines itself as "a group of people interested in politics who think we can make use of digital tools to monitor the work politicians do". Qué hacen los diputados provides a collaborative application where citizens can engage in various tasks: follow a politician and post the information they gather; scrutinise the official state bulletins; correct and redact the information collected by other contributors or edit information on collaborative spaces like 15MPedia or Wikipedia. Since its appearance, Qué hacen los diputados has published numerous reports containing detailed information about politicians' activities. A similar platform is Civio.org, an initiative inspired by MySociety, which began in February 2012, also in defence of "information transparency, accountability and openness of data through the use of technology". This platform has collaborated with Qué hacen los diputados since December 2012 and has specialised in publicly monitoring specific matters, such as the granting of pardons, transparency of local, regional and state administrations, and public assistance services. Another initiative is Sueldos Públicos, born in 2012, which focuses on promoting transparent coverage of the salaries and perks of elected representatives, and public spending patterns. The group describes its mission as "to report on management by our politicians, whose salary is paid by all taxpayers. We also publicise the abuses committed by those who exercise public power". 
Scrutiny by citizens' platforms has been applied in other spheres. As a consequence of the political and economic crisis, the spotlight has been turned on the dominant political parties, the economy and public debt. The citizens' initiative Cuentas Claras is particularly active in the field of political parties. It was launched by $15 \mathrm{M}$ activists in November 2011 following the pardon granted to Banco Santander executive Alfredo Saenz by the then socialist government of José Luis Rodríguez Zapatero. Since that time, Cuentas Claras has directed its monitoring work at the lack of transparency in Spanish political party funding. The platform demands that "in a democracy people have the right to control and monitor those who govern in their name ${ }^{2 \%}$. For its part, the Plataforma Auditoria Ciudadana de la Deuda (PACD, the Citizen Debt Audit Platform), formally constituted in March 2012, is the product of collaboration between activists from 15M, Democracia Real Ya (Real Democracy Now), Attac and Economistas sin fronteras (Economists without Borders). This platform's mission is to examine in depth the origins and causes of the economic crisis and Spanish debt. It focuses on how debt is generated and on identifying those who are responsible for the present crisis.

Table 2

\begin{tabular}{|c|c|c|c|}
\hline Platform & Mission & Website & $\begin{array}{l}\text { Founded } \\
\text { in }\end{array}$ \\
\hline Adopta un senador & $\begin{array}{l}\text { Publishes political } \\
\text { representatives' asset } \\
\text { statements in open format }\end{array}$ & $\begin{array}{l}\text { http://derecho- } \\
\text { internet.org/node/569 }\end{array}$ & 2011 \\
\hline $\begin{array}{l}\text { Qué hacen los } \\
\text { diputados }\end{array}$ & $\begin{array}{l}\text { Scrutinises political } \\
\text { representatives' daily } \\
\text { activities }\end{array}$ & http://quehacenlosdiputados.net/ & 2011 \\
\hline Cuentas Claras & $\begin{array}{l}\text { In-depth exploration of } \\
\text { opaque political party } \\
\text { funding methods }\end{array}$ & http://cuentas-claras.org/ & 2011 \\
\hline Civio.org & $\begin{array}{l}\text { Examines certain policies - } \\
\text { pardons, accountability, tax } \\
\text { investment and the } \\
\text { relationship between } \\
\text { institutions and citizens }\end{array}$ & http://www.civio.es/ & 2012 \\
\hline Sueldos Públicos & $\begin{array}{l}\text { Scrutinises politicians' } \\
\text { remuneration and abuses of } \\
\text { office }\end{array}$ & http://www.sueldospublicos.com/ & 2012 \\
\hline
\end{tabular}

In addition to this type of civil platform, which continuously monitors certain centres of power, in recent years collaborative scrutiny processes have also emerged.

\footnotetext{
${ }^{2}$ http://cuentas-claras.org/about/ (Accessed 10 December 2013).
} 
These collaborative initiatives examine or debate particular issues with the active cooperation of citizens. A prominent example is the 15MpaRato campaign. This initiative brought together the possibilities offered by crowdfunding and crowdsourcing for collaborative work, and has helped bring to justice both former IMF President Rodrigo Rato and board members of the Bankia IPO. This initiative began gathering information on the case with the collaboration of Internet users; a legal court case eventually resulted. The case cost around 15,000€; an appeal through a crowdfunding campaign raised $18,359 €$ in less than 24 hours from 965 donations and, within days, the complaint was filed (Tascón \& Quintana 2012, pp- 59-60). The press widely reported the news under the headline " $15 \mathrm{M}$ movement brings Rodrigo Rato and Bankia directors to justice",3.

The aforementioned Bárcenas case also gave rise to collaborative processes to monitor the unfolding scandal. Following the publication of the Bárcenas papers in $E l$ País, journalist and blogger Antonio Delgado asked on Twitter why the newspaper did not publish the information in an open format. The query triggered the launch of a crowdsourcing campaign calling for citizen cooperation through the hashtag \#adoptauncorrupto. Within hours, collaborative action had compiled the information in Google Docs and Excel formats. The Bárcenas case was linked in turn to another process of collaborative scrutiny, which followed the publication (July 8, 2013) of the official accounts of the PP for the period 1990-2011 by the hacktivist movement Anonymous. More than 5GB of information in raw data was collated. Although it included only materials linked to the official accounts -and not the slush fund donations- it still proved to be a sensation. It enabled information to be compared with the Bárcenas papers and contained accounting information for the 1990-1994 period, information that the political party executive had denied possessing. So as to leave no trace of who might be responsible, the raw information was provided by Anonymous through BayFiles. It was then organised with great efficiency and published through the public platform Cuentas Claras and the alternative newspaper Diagonal, both of which called on their readers for help.

\section{Direct action platforms to scrutinise legislation and political decisions}

\footnotetext{
${ }^{3} \mathrm{http}$ //es.euronews.com/2012/07/10/el-movimiento-15m-lleva-a-rodrigo-rato-y-la-directiva-de-bankiaante-la-justicia/ Accessed 4 January 2014).
} 
Another type of mobilisation that has gained significant ground in the Spanish political context since the advent of $15 \mathrm{M}$ is the street protests organised through heterogeneous direct action platforms. The mass demonstrations that broke out in 2011 were prompted by general complaints about incongruities within the political system: the absence of separation of powers, lack of transparency, economic lobbies manipulating politics and defective electoral laws. The demonstrations have since morphed into direct action initiatives that address specific issues and denounce abuses of power on questions such as mortgage law or cuts in health and education budgets. Since 2011, groups such as the Plataforma de Afectados por la Hipoteca (platform of people affected by mortgages) (PAH), founded in Barcelona in 2009, have made their presence felt. Other platforms include the Plataformas de Afectados por las Preferentes (platforms of those affected by preferred stock), the Plataforma en Defensa de la Sanidad Pública (platform for the defence of public health), the Plataforma en Defensa de la Enseñanza Pública (platform for the defence of public education), the Anti-fracking Platform and the iai@flautas (Old people's action group). Some of these local initiatives have spread across the whole country.

Among these different groups, the $\mathrm{PAH}$ is a significant case of an activist group that has successfully scrutinised and denounced Spanish mortgage laws, the banking system and the lack of response by elected representatives. In addition, the direct action of PAH has addressed the housing problem affecting a significant proportion of a population unable to meet mortgage repayments due to rising unemployment. This platform group, together with other groups linked to $15 \mathrm{M}$, has not only raised general public awareness about unfair clauses in numerous bank mortgage contracts and the need for agreements allowing in lieu repayments; it has so far blocked nearly a thousand evictions ${ }^{4}$. These blockades were made possible by tight organisation. Notices on the platform blog were subsequently spread by messages on social networks calling for street mobilisations, where hundreds of activists created human shields outside threatened houses.

The PAH's organisational capacity and strength have been felt on numerous occasions, in surprising ways. In February 2013, the platform's spokesperson, Ada Colau, was invited to address a commission of the Spanish parliament. Several months

\footnotetext{
${ }^{4}$ http://afectadosporlahipoteca.com/ (Accessed 18 February 2014).
} 
later, she appeared before the European Parliament. These two interventions afforded the opportunity to publicly denounce the Spanish mortgage laws. The PAH also tabled a popular legislative initiative in the Spanish parliament in February 2013. This intervention followed a campaign that gathered nearly 1.5 million signatures. Public support and active pressure in favour of the proposal, and the suicide of several citizens who were unable to meet their mortgage payments, forced the government to incorporate the bill into parliamentary debate, a move that was almost unheard of in Spanish democracy. The end result of this popular legislative initiative was unsuccessful; the bill finally approved (in April 2013) by the majority government failed to incorporate key elements, such as the acceptance of assets in lieu of payment. In spite of this, the PAH efforts led to several smaller amendments of the law and prompted several opposition parties to put the mortgage law question on their agendas. In addition, and coinciding with the legislative initiative, the $\mathrm{PAH}$ received positive news from the European Court of Justice, which in March 2013 ruled that some aspects of Spanish law were incompatible with the European consumer protection directive approved in 1993. Shortly afterwards, in June 2013, the PAH won the European Citizen Award from the European Parliament. This award brought international recognition to the work of the platform, whose claims were further strengthened by the report on social housing approved by the European Parliament, which urged the Spanish government to alter details of its mortgage legislation ${ }^{5}$.

During recent months, actions organised by citizens' platforms have spread into virtually all areas of public life affected by compulsory austerity. The right to housing, public health, public education, respect for the environment, the defence of public pensions, to mention a few, are concerns that citizens have mobilised around in order better to scrutinise the policy measures and legislative decisions made by politicians. Questions about who decides who gets what, when and why constantly arise among citizens organised in platforms; they have become unelected representatives (Author 2 $2013,55)$ in the polls and self-taught specialists in specific fields, as well as guardians of certain rights. In addition to the platforms mentioned above, others have emerged, such as the Plataforma en Defensa de la Enseñanza Pública. Its work focuses on

\footnotetext{
${ }^{5}$ European report is available at: http://www.europarl.europa.eu/sides/getDoc.do?type=REPORT\&reference=A7-20130155\&language $=$ EN\#title1 (Accessed 2 December 2013).
} 
monitoring education budget cuts, and the problems they produce. Other examples include the Anti-fracking Platform, which assesses and denounces the risks associated with hydraulic fracturing; and the Plataforma Afectados por las Preferentes, which organises collectively to take legal action against banks that improperly sold toxic financial products. Activist groups like iai@flautas (Old People's Action Group) support a wide range of other platforms and initiatives at the same time as they denounce pension cuts and the waste of public money on megaprojects.

All these platforms follow a common organisational pattern, one based on a combination of Internet organisation and street demonstrations. They use digital technologies to contact their supporters, present their manifestos and organise their street actions. Among the many different ways new communication tools are being used, online petitions have emerged as one of the most widespread tactics of online participation (Earl \& Kimport 2011). Online petitions allow digital votes to be collected through campaigns, and are a low-cost way of enabling rapid viral dissemination through multiple digital tools, such as social networks and microblogging spaces. A prominent example of an online petition platform is Change.org. Such initiatives try to establish links between the online environment and offline activism in order to move their demands beyond the Internet. To this end, protesters try to promote transparency and to influence political decisions by taking over public spaces with encampments, leading marches for democracy, and staging demonstrations, sit-ins and pacifist sieges of centres of power (Castells 2012).

\section{The emergence of new 'anti-party' parties}

A more recent phenomenon in the Spanish scene is the appearance of new political parties. Until recently, political activism has been expressed primarily through mobilisations and citizen initiatives, in order to influence the political class through external pressure. During the past year, these strategies have expanded to include political parties created at the grass roots by citizens themselves. These initiatives are guided by a different philosophy from that of the traditional parties, in that their goal is not to gain political power and professionalise political activity, but rather to draw attention to specific defects of the democratic system itself. The whole idea is that citizen groups try to use the party form and participate in elections as one more strategy -they do not presume it is the only one- to call attention to democratic shortcomings and the need for effective change (Tormey 2014 forthcoming). Some of the parties that 
have appeared in recent years include Escaños en Blanco (Empty Seats), Partido X (X Party), Construyendo la Izquierda (Building the Left), Podemos (We can) and Partido Pirata (Pirate Party).

The emergence of these new "anti-party" parties is linked to the potential offered by digital communication tools that enable the consolidation of complex political structures in a "ridiculously easy" way (Shirkey 2009). New parties manage to influence the public agenda, especially through the use of social media, despite having very few resources. Among the many parties that have appeared in recent years Escaños en Blanco and Partido $X$ are particularly noteworthy with regard to the way they publicly monitor the whole political system.

Escaños en Blanco (EB) was founded in 2010. Its origins predate 15M, with which it is not directly linked, but with which it shares some key concerns, such as lack of political transparency, defective electoral laws and the low turnover of political officials. This party has grown remarkably in terms of branches and numbers of affiliates across Spain during the past two years. It was set up with the stated aim of winning office but leaving empty seats in the national parliament, the senate and representative chambers at regional and local levels. They aim to do this by fielding election candidates who promised not to take up their parliamentary seats, so leaving an 'empty seat' as a reminder of the political anger and disillusionment of the voting public. Escaños en Blanco does not offer solutions to the wider economic and social crisis. Its purpose is to force politicians to reflect on what it considers to be the decline of political parties and elected representatives. Escaños en Blanco's strategy is defined by efforts to address the area where it knows it can exert the greatest effect on politics: elected chambers. Spotlighting public concern about disaffection by symbolically leaving parliamentary benches empty, EB's ultimate goal, its long-term normative horizon, is to achieve good and effective representation in parliament. It is supposed that when the point is reached that politicians act competently and responsively to the substantive interests of society, then the political party will dissolve itself.

EB's adoption of a particular form of 'anti-party' political party strategy supposes that the dominant political class can be influenced without the party actually participating in representative structures. A different strategy is pursued by the Partido $X$. Standing for the first time in the 2014 European elections, and claiming to be the party of all citizens, Partido $X$ is the brainchild of activists with close links to the $15 \mathrm{M}$. The aim of the party is to "disrupt the system" and thereby to create the basis for 
political change. Partido X calls for "Democracia y punto" (democracy, full stop). It advocates a political system that fosters deliberative direct participation in key decisions and exploits the possibilities for participation offered by new media communication tools.

Partido $X$ seeks to promote internal democracy within the party by creating a participatory and transparent process of election of its own representatives. Any supporter of the party - not necessarily formal members - may take part in the candidate selection process, stand as a candidate, nominate other candidates and, finally, vote for the members who will represent the party during elections. The party's own programme was drawn up collectively, with the active collaboration and participation of all those involved in the project. The whole process draws upon a wiki model, in which a group of experts initially draws up proposals, a second group of collaborators raises questions or concerns about these issues, a third group revises them for errata or possible contradictions, and so on. Using such methods, Partido $X$ not only seeks to create a new type of party; it also aims to highlight the limitations and dangers plaguing the traditional parties. The Partido $X$ is an 'anti-party' political party in the sense that it rejects the hierarchical structures and orthodox discourse of traditional political parties that make a fetish of the profiles and careers of a just a few key individuals: the 'politicians'.

It may seem strange to include political parties within the category of monitory democracy, but the reason why the Partido $X$ and EB can be considered monitory mechanisms is that their guiding motivation is to disrupt the mainstream democratic process, and to draw attention to its limitations and deficiencies (Tormey 2014 forthcoming). In some cases, the emphasis on the monitory understanding of democracy is explicitly stated. An example is Democracia y punto, which takes as its prime objective 'transparency in governance'. It is a political party that insists that citizenship "is the necessary caretaker of all decisions that affect it and of all public expenditure" The Partido $X$ similarly concludes that public scrutiny is "the only effective way to end corruption"7

What we see in the Spanish case, in other words, is the tendency of citizens' pressure groups to explore the political party form as an additional strategy for

\footnotetext{
${ }^{6} \mathrm{http}: / /$ partidox.org/programa/ (Accessed 3 February 2014).

${ }^{7} \mathrm{http}$ //partidox.org/red-ciudadana-partido-X-anuncia-creacion-de-comision-ciudadana-anticorrupcion/ (Accessed 3 February 2014).
} 
denouncing the failings of the existing democratic system and for achieving substantive political change. The whole tactic supposes that political parties are not ends in themselves, but only means to an end, and limited means at that. This naturally raises the interesting but still unanswered question of what would happen if one or a number of such anti-party political parties won so many votes that they would be faced with the prospect of governing, either in a coalition, or in their own right.

\section{Conclusions}

A wide and interesting variety of new monitoring processes are being consolidated in the current Spanish political scenario. Traditional and independent media, citizen platforms, direct action platforms and anti-party parties: all are more or less agreed about the need for new forms of action designed to shed light on fields of power that are presently opaque. There is widespread agreement as well that the perpetrators and culprits of the crisis need to be publicly exposed, and that for this purpose a multiplication and widening of the range of views articulated in the public sphere is urgently needed.

The main aim of this essay has been to analyse a complex political context, that of Spain, while using monitory democracy as a theoretical framework. The approach has not been widely used in the Spanish context, but we consider it advantageous in spotlighting important new dynamics. The Spanish political context is characterised, on the one hand, by symptoms common to many other democracies: the discrediting of the major parties, declining party membership and disaffection with the political class, among others, are all part of a striking trend. On the other hand, the Spanish case shows an unusually strong citizen predilection for rich democratic experimentation and innovation. Our analysis of citizens' responses to the political crisis in Spain seems to have no counterpart in either liberal interpretations of democracy or in so-called 'elitist' theories of democracy. The rotation of elites, model once championed the work of Schumpeter (2003, pp.269-273) certainly does not explain citizens' predilection for active involvement in political life. Furthermore, the Spanish political context can hardly be described as marked by apathy, disillusionment and the drift towards postdemocracy (Crouch 2004). For important sectors of Spanish society, politics has become an important part of everyday life and is expressed in multiple forms and through multiple dynamics. Active distrust of the major parties and the facts of the 
economic crisis have not combined to produce either a crisis of legitimacy or blind acceptance of the existing parliamentary democratic system. Quite the contrary: the whole country is witnessing widespread demands for the radical refurbishment and improvement of democracy. The demands and struggles for new monitory mechanisms are acquiring particular relevance. One major consequence of these dynamics is to put on the public agenda key questions to do with who gets what, when and how. Corruption and political incompetence have become central issues in the public sphere. Citizens' agendas and initiatives are producing a steady proliferation of monitory mechanisms that seek to expose, evaluate and transform the centres of economic and political power.

This essay suggests that the concept of monitory democracy developed elsewhere offers a strong interpretative framework for understanding some basic features of the complex political dynamics in contemporary Spain. The constant eruption and proliferation of scandals, public demonstrations, information leaks, collaborative scrutiny processes makes this perspective of monitory democracy suitable for analysing the Spanish political context with fresh methods, new concepts and a strong sense of the historical originality of the present moment.. Furthermore, this essay in a sense takes the concept of monitory democracy from theory to practice. It does so by introducing a basic category of citizen monitoring processes - the public scrutiny of power - and showing how the category is of great political relevance in the Spanish context.

The essay leaves open questions for further research, and for the refinement of the monitory democracy framework. One key question concerns that requires further analysis and reflection is whether and how different monitory mechanisms can be grouped under the traditional headings of for-profit and non-profit sectors. The distinction between the profit and non-profit actors in civil society theory has been discussed extensively during the past thirty years (Habermas 1996; Dekker \& van den Broek 1998; Author 21984 and 2005b; Glasius 2005; García Marzá 2008). However, our initial analysis of the contemporary Spanish scene suggests the difficulty of establishing strong divisions along these lines. In no small measure because of the spread of digital media networks, collaborative and hybrid initiatives that cut across the boundaries of private (for-profit) and independent non-profit organisations are commonplace when it comes to monitoring processes. The same goes for direct action platforms, which flexibly adopt either a for-profit or a non-profit character. 
Another open question concerns the possible sets of similarities of Spanish monitory mechanisms with scrutiny bodies that are developing in other national contexts. Related research has already examined other contexts where monitory processes are being practised and consolidated (Tragardh et al. 2013). Moreover, our analysis suggests that the partial obsolescence of the distinction between the 'domestic' and the 'foreign'. Some Spanish monitory bodies are heavily influenced by so-called foreign platforms and initiatives. Examples include. Qué hacen los diputados, which draws from opencongress.com (EE.UU) and openpolis.it (Italy); and Civio.org, which is modelled on MySociety (UK). Conversely, there are also cross-border foreign platforms, such as the German Zwangsräumung verhindern, which have been influenced by, and have links with, Spanish groups like the PAH. Finally, there are transnational groups - the Independent Media Center (Indymedia) and Anonymous are examples - that operate on a global scale and carry out sporadic monitoring processes without a strong national focus. An in-depth study of these cross-border monitory mechanisms certainly needs further research and reflection. Our analysis of the Spanish case nevertheless shows that the lack of accountability of key institutions, the high level of perceived corruption and the economic crisis together explain why a rich variety of monitory mechanisms has been consolidated in Spain, and why these scrutiny mechanisms are likely to play a vital role in the resolution of the current deep crisis, and the crises still to come.

\section{References}

Alves, M. A. (2013). Social Accountability as an Innovative Frame in Civic Action: The Case of Rede Nossa São Paulo. VOLUNTAS: International Journal of Voluntary and Nonprofit Organizations., Ddoi: 10.1007/s11266-013-9365-6

Andronikidou, A., \& Kovras, I. (2012). Cultures of Rioting and Anti-Systemic Politics in Southern Europe. West European Politics, 35:4, 707-725.

Anduiza, E., Cristancho, C. \& Sabucedo, J.M. (2013). Mobilization through Online Social Networks: the Political Protest of the Indignados in Spain. Information, Communication and Society, 1-15.

Bennett, W., L. \& Segerberg A. (2012). The Logic of Connective Action. Information, Communication \& Society, 15:5, 739-68.

Castañeda, E. (2012) The Indignados of Spain: A Precedent to Occupy Wall Street.Social Movement Studies, 11(3-4): 309-19.

Castells, M. (2012). Networks of Outrage and Hope: Social Movements in the Internet Age. Cambridge: Polity Press.

Charnock, G., Purcell T. \& Ribera-Fumaz, R. (2011). ¡Indígnate!: the 2011 Popular Protest and the Limits to Democracy in Spain. Capital and Class, 31, 3-11.

Crouch, C. (2004). Post-Democracy. Cambridge: Polity. 
Dekker, P. ., \& van den Broek, A. (1998). Civil Society in Comparative Perspective: Involvement in Voluntary Associations in North America and Western Europe. VOLUNTAS: International Journal of Voluntary and Nonprofit Organizations, 9 (1), 11-38.

Della Porta, D. (2011). Communication in Movement: Social Movements as Agents of Participatory Democracy. Information Communication and Society, 14(6): 800-819.

Della Porta, D. (2013). Can Democracy be Saved? Participation, Deliberation and Social Movements. Cambridge: Polity.

Earl, J. \& Kimport, K. (2011). Digitally Enabled Social Change. Activism in the Internet Age. Massachusetts: MIT Press

FnfEurope (2013). The Spanish Slump - Political Crisis and the Need for Institutional Reform. Available at: http://fnf-europe.org/2013/06/17/the-spanish-slump-political-crisis-and-theneed-for-institutional-reform/ (Accessed 27 November 2013).

García-Marzá, D. (2008). Sociedad civil: una concepción radical. Recerca. Revista de Pensament i Anàlisi, 8, 28-32.

Glasius, M. (2005). Commentary on Keane: "Eleven Theses on Markets and Civil Society", Journal of Civil Society, 1 (1), 39-42.

Habermas, J. (1996). Between Facts and Norms. Contributions to a Discourse Theory of Law and Democracy. Cambridge: MIT Press.

Hughes, N. (2011). "Young People Took to the Streets and all of a Sudden all of the Political Parties Got Old: The 15M Movement in Spain“, Social Movement Studies, 10:4, 407-13.

Kennedy, P. (2012). From Unpopular Socialists to the Popular Party: The Spanish General Election of 2011. West European Politics, 35:3, 673-81,

Kovach, B., \& Rosenstiel T. (2007). The Elements of Journalism: What Newspeople Should Know and the Public Should Expect. New york: Three Rivers Press.

Lievrouw, L. (2011)- Alternative and activist new media. Cambridge: Polity.

Micó, J.L., \& Casero-Ripollés, A. (2013). Political Activism Online: Organization and Media Relations in the Case of 15M in Spain Information, Communication and Society, 1-16.

Moffitt, B. \& Tormey, S. (2013). Rethinking Populism: Politics, Mediatisation and Political Style. Political Studies, 1-17.

Munck, G.L. (2009). Measuring Democracy: A Bridge Between Scholarship and Politics. Baltimore: Johns Hopkins University Press.

Postill, J. (2013). Democracy in an Age of Viral Reality: A Media Epidemiography of Spain's Indignados Movement. Ethnography, 23, 1-19.

Przeworski, A. (2010), Democracy and the Limits of Self-Government. New York:Cambridge University Press.

Przeworski, A., Stokes, S., \& Manin. B. (eds.) (1999), Democracy, Accountability, and Representation. New York: Cambrige University Press.

Rosavallon, P. (2008). Counter-democracy: Politics in an Age of Distrust. New York: Cambridge University Press.

Saward, M. (2010). The Representative Claim. Oxford: Oxford University Press.

Schumpeter, J. A. (2003). Capitalism, Socialism and Democracy. London: Routledge.

Shirkey, Clay (2009). Here Comes Everybody: The Power of Organizing Without Organizations. New York: Penguin.

Taibo, C. (2013). The Spanish Indignados: A Movement with Two Souls. European Urban and Regional Studies, 20, 155-158.

Tascón, M. \& Quitana, Y. (2012) Ciberactivismo. Las nuevas revoluciones de las multitudes conectadas. Madrid: Catarata.

Toret, J. (ed.) (2013). Tecnopolitica: la potencia de las multitudes conectadas. El sistema red $15 \mathrm{M}$, un nuevo paradigma de la política distribuida. Barcelona: UOC.

Tormey, S. (2006). Not in my Name': Deleuze, Zapatismo and the Critique of Representation. Parliamentary Affairs, 59(1), 1-17

Tormey, S. (2014, forthcoming). Politics after Representation.

Tragardh, L. Witoszek, N. \& Taylor B (eds.) (2013) Civil Society in the Age of Monitory Democracy New York: Berghahm Books. 
von Hayek, F. (1979). Law, Legislation and Liberty: The Political Order of a Free People. London: University of Chicago Press.

Weber, M. (1978). Economy and Society. California: University of California Press.

Author $1(2012 \mathrm{a})$

Author $1(2012 b)$

Author $1(2012 \mathrm{c})$

Author 2 (1984)

Author 2 (2005a)

Author 2 (2005b)

Author 2 (2009)

Author 2 (2013) 